\title{
Low systemic testosterone levels induce androgen maintenance in benign rat prostate tissue
}

\author{
Ye Zhou, Maya Otto-Duessel, Miaoling He, Susan Markel, Tim Synold and \\ Jeremy $O$ Jones
}

Department of Molecular Pharmacology, Beckman Research Institute, City of Hope National Medical Center, 1500 E Duarte Road, Beckman 2310, Duarte, California 91010, USA
Correspondence should be addressed to $\mathrm{J} O$ Jones Email jjones@coh.org

\begin{abstract}
Prostate cancer (PC) is both an age- and an androgen-dependent disease. Paradoxically, systemic levels of androgens decline with age as the risk of PC rises. While there is no correlation between systemic androgen levels and the risk of PC, systemic androgen levels do not reflect the levels of androgens in prostate tissue. In metastatic PC, changes in the androgen biosynthesis pathway during hormone therapy result in increased levels of androgens in cancer tissue and contribute to continued androgen receptor (AR) signaling. It is possible that similar changes occur in normal prostate tissue as androgen levels decline with age and that this contributes to tumorigenesis. In the present study, we sought to determine whether the rat prostate is able to maintain functional levels of androgens despite low serum testosterone levels. Rats were castrated and implanted with capsules to achieve castrate, normal, sub-physiological, and supra-physiological levels of testosterone. After 6 weeks of treatment, LC-MS/MS was used to quantify the levels of testosterone and dihydrotestosterone (DHT) in the serum and prostate tissue. Quantitative RT-PCR was used to quantify the expression of genes involved in the androgen/AR signaling axis. Despite significantly different levels of testosterone and DHT being present in the serum, testosterone and DHT concentrations in prostate tissue from different testosteronetreatment groups were very similar. Furthermore, the expression of androgen-regulated genes in the prostate was similar among all the testosterone-treatment groups, demonstrating that the rat prostate can maintain a functional level of androgens despite low serum testosterone levels. Low-testosterone treatment resulted in significant alterations in the expression of androgen biosynthesis genes, which may be related to maintaining functional androgen levels.
\end{abstract}

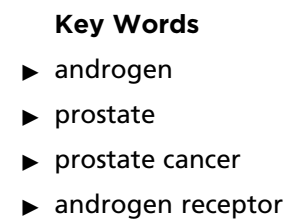

Journal of Molecular Endocrinology (2013) 51, 143-153

\section{Introduction}

Androgens and the androgen receptor (AR) signaling pathway are intimately associated with prostate carcinogenesis, and androgen deprivation therapy remains the most effective way to prevent the growth of metastatic prostate cancer (PC; Miyamoto et al. 2004). However, the relationship between androgen levels and the initiation of $\mathrm{PC}$ is still unclear. The risk of PC, an androgen-dependent disease, is highly associated with age, but serum levels of androgens are known to decline with age (Feldman et al. 2002). Many groups have studied the relationship between

Published by Bioscientifica Ltd. 
serum androgen levels and PC risk, and the consensus is that elevated systemic androgen levels do not correlate with PC incidence (Roddam et al. 2008, Morgentaler 2009). However, several cross-sectional studies have found that a low testosterone level at the time of PC diagnosis is correlated with a more aggressive disease (Schatzl et al. 2001). Additionally, in one of the largest and most thorough analyses to date, low serum dihydrotestosterone (DHT) levels have been associated with an increased risk of PC (Goldenberg et al. 2011). Furthermore, a study in a genetically engineered mouse model of human cancer (Nkx3-1; Pten mutant mouse) has shown that prolonged exposure to low levels of testosterone accelerates tumor progression and leads to a more aggressive disease than exposure to normal or castrate levels of testosterone (Banach-Petrosky et al. 2007). While these studies are far from conclusive, it appears that low systemic androgen levels may be associated with an increased risk of PC incidence and aggressiveness.

A major shortcoming of all of these studies is that they used serum androgen levels as a surrogate for prostate tissue androgen levels. It has been clearly demonstrated that prostate and PC tissues are only modestly influenced by serum levels of androgens. Studies on the molecular impact of testosterone replacement therapy (TRT) as well as of male hormonal contraception on intraprostatic androgen concentration and androgen action indicate that the intraprostatic level of androgen is not affected by testosterone supplementation (Marks et al. 2006, Page et al. 2006, Morgentaler \& Traish 2009, Goldenberg et al. 2011, Mostaghel et al. 2012). A small study in medically castrated healthy men has further revealed that despite a 94\% decrease in serum testosterone levels with medical castration, intraprostatic testosterone and DHT levels remain $20-30 \%$ of the control values and that prostate cell proliferation, apoptosis, and androgen-regulated protein expression are not affected (Page et al. 2006). These results suggest that the prostate may behave like a buffer that can maintain the intraprostatic level of androgen despite a wide range of serum levels. However, how the prostate buffers androgen concentrations in the milieu of a wide range of systemic androgens is still unclear.

A similar phenomenon occurs in metastatic PC tissue where, despite castrate levels of androgens in the blood, testosterone and DHT levels in the cancer tissue are sufficient to activate AR signaling and drive cancer growth (Nadiminty \& Gao 2012). Several mechanisms have been proposed to explain the continued AR signaling in castration-resistant PC (CRPC), chief among them are the changes that allow for the increased uptake of adrenal androgens (Bosland 2000, Chen et al. 2004, Labrie et al. 2005, Stanbrough et al. 2006, Nadiminty \& Gao 2012), de novo intracellular androgen synthesis (Locke et al. 2008, Montgomery et al. 2008, Cheng et al. 2010, Nadiminty \& Gao 2012), and downregulation of steroid metabolism (Soronen et al. 2004), as well as amplification and overexpression of the AR and its splice variants (Chen et al. 2004, Guo et al. 2009, Waltering et al. 2009, Hornberg et al. 2011, Shiota et al. 2011). We reasoned that many of the same mechanisms may be responsible for the ability of the normal prostate to maintain relatively constant levels of testosterone and DHT despite a wide range of androgens in the blood, especially in the setting of a low-testosterone environment, which is often observed in older men.

To test our hypothesis, we first sought to determine whether the rat prostate could be used to model intraprostatic androgen maintenance. We also comprehensively examined the expression of genes in the androgen/AR signaling pathway to determine whether changes in these genes correlated with the ability of the rat prostate to maintain androgen levels. We found that the normal rat prostate, much like the CRPC tissue, has altered expression of genes in the androgen/AR signaling axis in response to low serum testosterone levels, which results in the ability of the prostate to sustain functional intraprostatic androgen levels.

\section{Materials and methods}

\section{Animal protocol}

This study was carried out in strict accordance with the recommendations in the Guide for the Care and Use of Laboratory Animals of the National Institutes of Health and was approved by the City of Hope IACUC (11036). A total of 28 male Sprague-Dawley rats (8 weeks old, postpubertal) were purchased from Harlan Laboratories (Indianopolis, IN, USA) and were fed water and rat chow ad libitum. A cohort of rats $(n=4)$ was kept intact as a control for the experiments. The remaining rats were randomly divided into four groups (six rats/group) and castrated to eliminate the endogenous source of androgens. The manipulation of testosterone was achieved using silastic capsules, which were implanted subcutaneously via a small skin incision at the same time as castration. Testosterone was purchased from Steraloids (Newport, RI, USA). According to published results, testosterone capsules were designed to have a release rate

Published by Bioscientifica Ltd. 
of $11.5 \mu \mathrm{g} /$ day for the testosterone $0.5 \mathrm{~cm}$ group, $46 \mu \mathrm{g} /$ day for the testosterone $2 \mathrm{~cm}$ group, or $110 \mu \mathrm{g} /$ day for the testosterone $5 \mathrm{~cm}$ group, which allowed us to administer sub-physiological, normal, or supra-physiological levels of testosterone (Moger 1976, Vanderschueren et al. 2000). Six weeks later, the rats were killed, serum was collected by cardiac puncture, and testosterone and DHT levels were measured using HPLC-MS/MS. Prostates were also harvested, weighed, and prepared for gene expression analysis or immediately frozen for the measurement of testosterone and DHT concentrations.

\section{Androgen concentration measurements}

Testosterone and DHT concentrations were determined by mass spectrometry using methods adapted from those that have been described previously (Montgomery et al. 2008). In brief, frozen tissue samples were individually thawed, weighed, and homogenized in $\mathrm{H}_{2} \mathrm{O}$ at a concentration of $100 \mathrm{mg} / \mathrm{ml}$. Later, $100 \mu \mathrm{l}$ of homogenates or serum were spiked with internal standard 3-deuteride-testosterone (testosterone-d3) and DHT-d3, diluted with $400 \mu \mathrm{l}$ water, and extracted with $5 \mathrm{ml}$ hexane. The organic phase was transferred and evaporated to dryness. Each individual concentrated extract was dissolved in $0.1 \mathrm{M}$ hydroxylamine hydrochloride in 50\% methanol/water and incubated for $1 \mathrm{~h}$. Standards for DHT and testosterone were prepared in parallel. The resulting oximes were analyzed by HPLC-MS/MS using an Agilent Technologies LC 1100 series system (Palo Alto, CA, USA) interfaced with a Micromass Quattro Ultima Triple Quadrupole Mass Spectrometer (Micromass, Inc., Milford, MA, USA). MassLynx version 4.1 Software (Micromass) was used to acquire and analyze data. Separation of analytes was achieved on a Kinetex $2.6 \mu \mathrm{m} 100 \times 2.1 \mathrm{~mm}$ C18 column (Phenomenex, Torrance, CA, USA). Ions monitored were $\mathrm{m} / \mathrm{z} 304.5>124.25$ and $307.5>112.25$ for testosterone and testosterone-d3 respectively and $m / z \quad 347.55>306.45$ and 350.55>309.45 for DHT and DHT-d3 respectively. Limits of detection (defined as a $\mathrm{S} / \mathrm{N} \geq 5$ ) for testosterone and DHT were 0.02 and $0.01 \mathrm{ng} / \mathrm{ml}$ respectively.

\section{Estradiol and DHEA ELISAs}

DHEA and estradiol $\left(\mathrm{E}_{2}\right)$ concentrations were determined by ELISA (DHEA: APLCO, Salem, NH, USA; $\mathrm{E}_{2}$ : Diagnositc Automation, Inc., Calabasas, CA, USA). The sensitivities of the DHEA and $\mathrm{E}_{2}$ ELISAs were $00.108 \mathrm{ng} / \mathrm{ml}$ and $10 \mathrm{pg} / \mathrm{ml}$ respectively. The crossreactivity of the DHEA assay with other steroids is
$<0.1 \%$, and the cross-reactivity of the $\mathrm{E}_{2}$ assay with other steroids is $<2 \%$. The measurable ranges for DHEA and $\mathrm{E}_{2}$ are $0-30 \mathrm{ng} / \mathrm{ml}$ and $0-1000 \mathrm{pg} / \mathrm{ml}$ respectively.

\section{RNA isolation and quantitative RT-PCR}

Total RNA was isolated using a PARIS kit (Ambion, Carlsbad, CA, USA), followed by treatment with DNAse using the Qiagen RNase-Free DNase Set (Qiagen, Inc.). cDNA was generated from each sample using $250 \mathrm{ng}$ of total RNA in an oligo dT-primed RT reaction. Quantitative RT-PCRs (qRT-PCRs) were performed in triplicate using a StepOne Real Time PCR system (Applied Biosystems) with $\sim 2.5 \mathrm{ng}$ of cDNA, $1 \mu \mathrm{M}$ of each primer pair, SYBR Green (Invitrogen) as the detecting dye, Rox (Invitrogen) as the reference dye, and Taq PCR kit (Qiagen, Inc.). Primers specific for the genes of interest were designed using the web-based primer design service PrimerQuest provided by Integrated DNA Technologies (Coralville, IA, USA). To analyze $A r$ variant mRNA expression, we adapted the primers previously reported specific to AR splice variants in humans (Dehm et al. 2008, Guo et al. 2009, Hu et al. 2009b, Sun et al. 2010). Sequences are provided in Supplementary Table 1, see section on supplementary data given at the end of this article.

\section{Cloning and sequencing of $A r$ variant transcripts}

For each sample, $2 \%$ cDNA product from $250 \mathrm{ng}$ of input total RNA was used. PCR products derived from the primer pairs that span the region of exons $1-3$ and 1-8 of the Ar gene (Supplementary Table 1) were cloned into TopoTA vector (Invitrogen) and subjected to a sequencing analysis at the DNA sequencing core facility (City of Hope).

\section{Statistical analysis}

The serum and tissue androgen concentrations are expressed as mean \pm s.D. The significance of differences was determined using ANOVA followed by a Tukey's correction. $P$ values $<0.05$ were considered significant. For the analysis of the qRT-PCR data, the mean cycle threshold (Ct) obtained for each gene was normalized to the expression of the housekeeping gene Rpl19 in the same sample (the $\Delta C \mathrm{t}$ ). The specificity of amplification in each reaction was assessed based on the melting point of the dissociation curve. The fold change was calculated by taking the inverse log of the difference in mean $\Delta C t$ values between the treatment groups and the intact group.

Published by Bioscientifica Ltd. 
One-way ANOVA followed by a Tukey's correction was used for planned comparisons between the treatment groups that were defined by linear contrast statements. A $P$ value $<0.05$ was considered significant.

\section{Results}

\section{Functional levels of androgens are maintained in the prostate despite low serum testosterone levels}

To determine the relationship between serum and prostate tissue androgen levels in rats, rats were castrated to remove the endogenous source of testicular androgens and implanted with silastic capsules for delivery of zero, low, normal, or high levels of testosterone. We maintained a group of rats that had not been castrated or otherwise manipulated, which provided a control for the endogenous levels of testosterone and DHT (the intact group). After 6 weeks, the serum and intraprostatic concentrations of testosterone and DHT were assessed by LC-MS/MS analysis.

The serum and prostate tissue levels of testosterone and DHT in each rat are shown in Fig. 1. Intact rat serum testosterone levels were $4.48 \pm 1.72 \mathrm{ng} / \mathrm{ml}$ and DHT levels were $0.18 \pm 0.09 \mathrm{ng} / \mathrm{ml}$. Serum DHT levels were below the level of detection $(0.03 \mathrm{ng} / \mathrm{ml})$ in all the castrated rats and serum testosterone levels were below the level of detection in two of six rats, with the remainder exhibiting levels averaging only $0.04 \mathrm{ng} / \mathrm{ml}$. The values of testosterone levels were corroborated by ELISA (data not shown). We observed a linear correlation between the size of testosterone implant and serum testosterone and DHT levels, as expected. While the normal testosterone-treated group had similar serum testosterone and DHT levels compared with the intact group $(3.98 \pm 1.63 \mathrm{ng} / \mathrm{ml}$ for testosterone and $0.09 \pm 0.03 \mathrm{ng} / \mathrm{ml}$ for DHT), serum levels of testosterone $(1.30 \pm 0.25 \mathrm{ng} / \mathrm{ml}, P=0.0305)$ and DHT $(0.02 \pm 0.02 \mathrm{ng} / \mathrm{ml}, P=0.0171)$ were significantly lower in the low-testosterone-treated group than in the intact group. The group receiving high-testosterone implants had serum testosterone $(9.95 \pm 2.77 \mathrm{ng} / \mathrm{ml}, P<0.0001)$ and DHT $(0.26 \pm 0.14 \mathrm{ng} / \mathrm{ml}, P<0.0001)$ concentrations significantly higher than those in the intact group or in rats receiving either low or normal doses of testosterone. The differences in serum androgen levels were reflected in the wet weight of the prostates, although these differences were not statistically significant when compared with those of the intact group (Fig. 1E). Hightestosterone treatment resulted in widespread hypertrophy as indicated by increased glandular folding and hyperchromatic nuclei (Fig. 1I, compare with intact in $\mathrm{H}$ ), while castration resulted in severely atrophied and compact glands devoid of secretory cells (Fig. 1J). The low-testosterone-treated rat prostates had multiple atrophic foci, as evidenced by glands with flattened epithelial layers (Fig. 1K), but there were no other major abnormalities in the low-testosterone-treated rat prostates.

While serum testosterone and serum DHT levels were correlated $(r=0.87)$, neither prostate testosterone nor prostate DHT levels correlated with serum testosterone levels ( $r=0.06$ and $r=-0.02$ respectively). Despite varied serum androgen levels, intraprostatic concentrations of testosterone and DHT were not significantly different among the treatment groups (Fig. 1F). Although the serum levels of testosterone and DHT in the low-testosterone group were only 29 and $12 \%$ of those in the intact group, the levels of testosterone and DHT in the prostates of the low-testosterone group were 64 and $71 \%$ as much as those in the prostates of the intact group. A converse phenomenon was observed in the high-testosterone group. Although serum levels were markedly higher, tissue levels of testosterone and DHT were only 29 and $58 \%$ of those in the intact group - lower than those in the low-testosterone group. Although these comparisons were made on a permilligram-of-tissue basis, adjusting for prostate size to calculate the total androgenic content of the prostate in each rat led to the same conclusions. Our results are consistent with those of other studies that have shown that the relationship between serum and prostate tissue levels of androgens is not linear. Furthermore, the levels of androgens in the prostate of all the testosterone-treatment groups appeared to be functional as there was no significant difference in the expression of androgenregulated genes among the groups, while the expression of these genes was significantly different in the castrated group (Fig. 1G). Our results suggest that the rat prostate can preserve functional levels of testosterone and DHT despite low serum levels and is, therefore, an adequate model for studying the mechanism of intraprostatic androgen maintenance.

\section{Altered expression of $A R$ and genes mediating androgen uptake in the low-testosterone environment}

To investigate the mechanisms responsible for the maintenance of androgens in the prostate in the setting of low serum testosterone levels, we used qPCR to quantify the expression of genes known to be involved in the androgen/AR signaling axis (Table 1 and Supplementary Table 1). We first examined the expression of AR and

Published by Bioscientifica Ltd. 

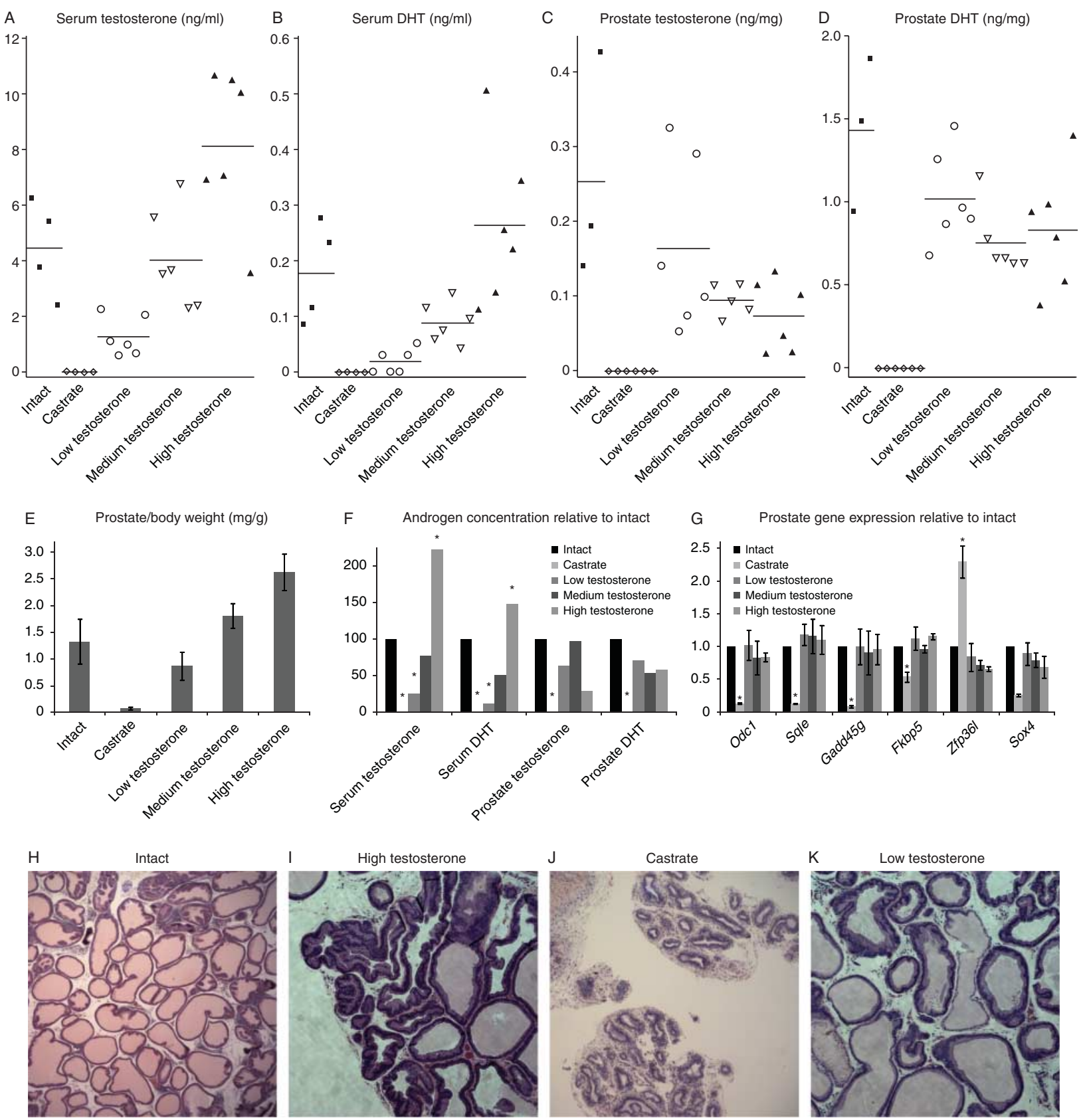

Figure 1

Serum and prostate tissue levels of androgens. The levels of serum testosterone (A), serum DHT (B), prostate testosterone (C), and prostate DHT (D) are shown for each rat. (E) Average wet prostate weight of each treatment group. (F) The average concentration of testosterone and DHT in each treatment group compared with that in the intact group. (G) Relative gene expression for a panel of androgen-responsive genes in the prostates of each treatment group compared with that in the intact group. Though

known steroid-transporter genes including the Slco gene family (Slco2b1, Slco1b3, Slco1a5, and Slco2a1), androgen-binding protein $(A b p(S h b g))$, which is the homolog of the human steroid hormone-binding globulin serum androgen levels were vastly different, prostate tissue androgen levels were very similar in all the testosterone-treatment groups, leading to equivalent androgen-dependent gene expression. $(\mathrm{H}, \mathrm{I}, \mathrm{J}$ and $\mathrm{K}$ ) Representative $H \& E(20 \times$ magnification) staining of intact $(H)$, high-testosterone $(\mathrm{I})$, castrated $(\mathrm{J})$, and low-testosterone $(\mathrm{K})$ rat prostates. Statistically significant differences in the intact group (ANOVA, $P<0.05$ ) are indicated by *.

$(S H B G)$ gene, and LDL-related protein 2 ( $\operatorname{rrp} 2$, or megalin). Notably, in the low-testosterone group, AR expression was increased $(P=0.0099)$, while AR expression in other groups was comparable to that in the intact group. 
Table 1 Relative expression of genes in different testosteronetreatment groups (fold change) vs the intact group ( $P$ values in the low-testosterone-treated group are indicated; statistically significant differences (ANOVA, $P<0.05$ ) from other groups are indicated by *). Additional genes examined without significant differences when compared with those in the intact group: Cyp11a1, Cyp17a1, Hsd3b2, Akr1c1, Akr1c2, Akr1c3 (Akr1c18), Srd5a1, Srd5a2, Slco1b3, Slco1a5, and Slco2a1

\begin{tabular}{|c|c|c|c|c|}
\hline Genes & $\begin{array}{c}\text { Low } \\
\text { testosterone } \\
(P \text { value })\end{array}$ & $\begin{array}{l}\text { Medium } \\
\text { testosterone }\end{array}$ & $\begin{array}{l}\text { High } \\
\text { testosterone }\end{array}$ & Castrated \\
\hline$A r$ & $1.7(0.009)$ & 0.93 & 1.15 & 0.96 \\
\hline Slco $2 b 1$ & $1.1(0.998)$ & 0.82 & 0.69 & $4.48^{*}$ \\
\hline$A b p$ & $1.87(0.121)$ & 1.00 & 1.72 & 0.59 \\
\hline Lrp2 & $1.8(0.427)$ & 1.02 & 0.98 & 1.50 \\
\hline$H s d 3 b 1$ & $2.03(0.042)$ & 1.36 & 1.16 & 0.40 \\
\hline$H s d 17 b 1$ & $2.74(0.008)$ & 1.91 & 2.06 & 1.22 \\
\hline Hsd17b3 & $3.67(0.029)$ & 2.98 & 2.76 & 3.21 \\
\hline Hsd17b6 & $2.92(0.005)$ & 1.19 & 0.52 & 0.16 \\
\hline Rdh5 & $2.25(0.041)$ & 2.04 & 1.60 & 1.37 \\
\hline Srd5a3 & $1.68(0.083)$ & 1.46 & 1.59 & 0.80 \\
\hline Hsd17b7 & $1.06(0.998)$ & 0.98 & 1.23 & $0.33^{*}$ \\
\hline Hsd17b10 & $1.56(0.015)$ & 0.98 & 1.27 & 0.97 \\
\hline Сур19a1 & $1.60(0.037)$ & 1.20 & 1.37 & 0.83 \\
\hline Sult1e1 & $3.32(0.112)$ & 1.85 & 1.21 & 0.69 \\
\hline Hsd17b2 & $3.07(0.140)$ & 2.14 & 2.13 & 1.98 \\
\hline Gusb & $4.06(0.635)$ & 3.50 & 1.98 & 2.72 \\
\hline Arsc1 & $1.72(0.081)$ & 1.30 & 1.21 & 1.20 \\
\hline
\end{tabular}

This suggests that there is pressure to increase AR expression in normal prostate in response to low serum androgen levels much like in the metastatic PC tissue. We also attempted to detect the expression of $A R$ splice variants documented in human CRPC, including AR-V1, AR-V7, AR3-5, and AR567es (Dehm et al. 2008, Guo et al. 2009, Hu et al. 2009b, Sun et al. 2010); however, we were not able to detect the expression of any of these variants, which may be because rats do not have equivalent AR variants to those in humans. To further identify novel AR splice variants in rats, we amplified the regions spanning exons 1-3 and 1-8 of the Ar gene, but we did not detect any transcripts of unexpected lengths, which suggests that there may be no detectable AR splice variants in our rat prostate samples. The only steroidtransporter gene to show any significant difference among the treatment groups was Slco2b1, the expression of which was significantly increased in the castrated group than in the intact group $(P<0.0001)$. This suggests that in the rat prostate, a prime response to castration is the specific upregulation of Slco2b1 expression. In humans, the protein that this gene encodes regulates the uptake of sulfated steroids (Smith et al. 2005), though what molecules it normally transports in rats is unknown. One of its major substrates in humans, DHEAS, is only produced at very low levels in rats (Cutler et al. 1978). Furthermore, we were not able to detect any DHEA in the rat prostate tissue by ELISA.
However, it appears that the increased expression of Slco2b1 is not important for the ability of the rat prostate to maintain androgen levels in our low-testosteronetreated group as its expression in these rats was very similar to that in the intact group. Although we found slight increases in the levels of expression of $L r p 2$ as well as $A b p$ in response to low serum testosterone levels, the changes were not significant ( $\operatorname{rrp} 2, P=0.4272 ; A b p, P=0.1218$ ).

\section{Alterations in genes encoding steroidogenic enzymes in the low-testosterone-treated group}

To investigate the role of steroid synthesis enzymes in intraprostatic androgen maintenance, we quantified the levels of transcripts encoding many enzymes involved in this process. Compared with the intact group, the lowtestosterone-treated group demonstrated significant increases in the expression of $H s d 3 b 1, H s d 17 b 3, H s d 17 b 6$, $R d h 5$, Srd5a3, and Hsd17b10, genes encoding key enzymes required for the metabolism of cholesterol to testosterone and DHT (Table 1). The expression of Cyp11a1, Hsd17b2, Gusb, and Arsc1 (Sts) was increased in the low-testosterone group relative to the intact group as well, but the changes did not reach statistical significance. Nearly all of these changes were more pronounced in the low-testosterone group than in the normal and hightestosterone groups, suggesting a stronger selection for the upregulation of these genes in the low-testosterone environment. The changes in the expression of these genes would be predicted to lead to an increased synthesis of testosterone and/or DHT (Fig. 2). Interestingly, the expression of Cyp19a1, the gene encoding the aromatase enzyme that converts testosterone to $\mathrm{E}_{2}, H s d 17 b 1$, the gene encoding the enzyme involved in the conversion of estrone $\left(\mathrm{E}_{1}\right)$ to $\mathrm{E}_{2}$, and Sult1e1, the gene encoding the enzyme that metabolizes $\mathrm{E}_{2}$ to $\mathrm{E}_{2}$-sulfate, was also upregulated in the low-testosterone-treated group. However, $\mathrm{E}_{2}$ was below the limit of detection by ELISA ( $5 \mathrm{pg} / \mathrm{mg}$ ) in all our rat prostate samples, so it is unclear how the changes in the estrogen pathway affect tissue hormone levels. Taken together, our results suggest that low serum levels of androgens may lead to changes in the steroidogenic pathway in the prostate that allow it to synthesize testosterone and DHT de novo or convert unidentified precursor androgens to maintain functional levels of androgens.

\section{Discussion}

The complex relationship between serum and prostate tissue androgen levels and the risk of PC is not well

Published by Bioscientifica Ltd. 


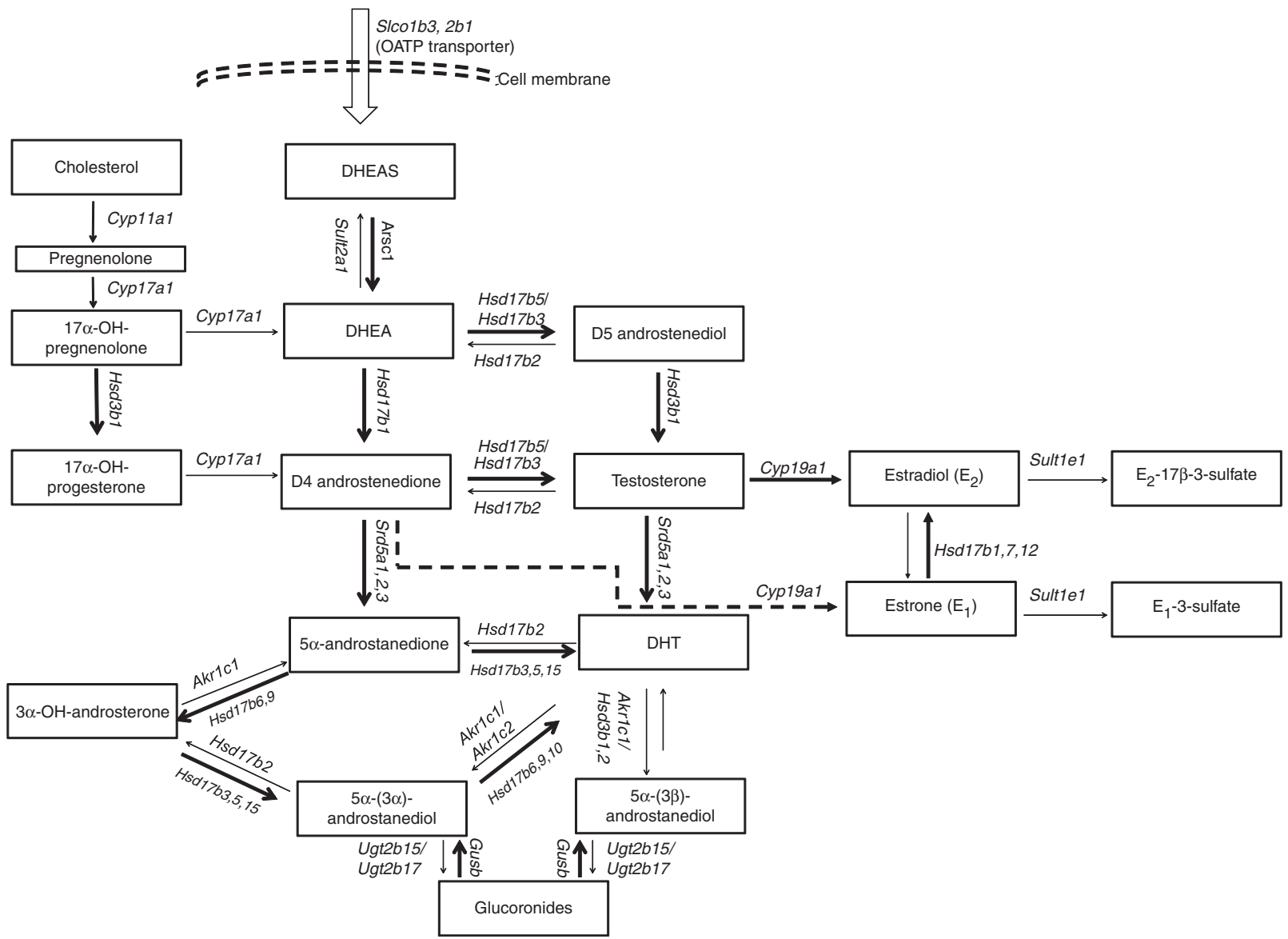

Figure 2

Changes in steroid biosynthesis pathway leading to testosterone and DHT accumulation. Genes in which statistically significant changes occurred in the low-testosterone-treated rats vs intact rats are in bold. These changes would be predicted to lead to increased levels of testosterone and DHT.

understood. Here, we confirm the results of other studies that have shown that the rat can provide a useful model for understanding the relationship between serum and prostate tissue androgen levels (Kyprianou \& Isaacs 1987a). We found that despite a wide range of serum testosterone levels, the levels of androgens in the prostate were fairly constant and not related to serum testosterone levels, which has been shown previously by Kyprianou \& lsaacs (1987b). Kyprianou \& lsaacs treated castrated rats with various sizes of silastic testosterone capsules to demonstrate that 'androgen-induced increase in prostatic cell number occurs as a quantal process that can only begin when the concentration of prostatic DHT is above a critical threshold value (i.e. $0.4 \mathrm{ng} / 10^{8}$ cells for the rat ventral prostate)'. We anticipate that a similar threshold exists for maintaining androgen-dependent signaling in the prostate and, furthermore, that a threshold exists for the concentration of blood androgens necessary to maintain tissue androgens. We also suspect that this threshold impacts tumorigenesis because in the Nkx3-1/Pten knockout model, castration reduces PC incidence but low testosterone levels increase the incidence (Abate-Shen et al. 2003).

Our findings in rats also parallel previous findings in humans (Page et al. 2006, Morgentaler 2009, Morgentaler \& Traish 2009, Goldenberg et al. 2011). Page et al. (2011) found that either medical castration or androgen supplementation in healthy men resulted in substantial changes in serum testosterone levels, while intraprostatic testosterone or DHT concentrations were relatively unaffected. Likewise, in a study of 44 men, Marks et al. (2006) demonstrated that 6 months of TRT normalizes serum androgen levels but does not affect prostate tissue androgen levels and cellular functions. In the setting of PC, several studies have found that intraprostatic androgen levels are preserved despite castrate serum

Published by Bioscientifica Ltd. 
testosterone and DHT levels following androgen deprivation therapy (Mohler et al. 2004, Montgomery et al. 2008). Moreover, these levels of intraprostatic androgens are sufficient to maintain important biological processes within the gland as evidenced by the continued expression of androgen-regulated genes. Likewise, we found that androgen levels in the prostates of the lowtestosterone-treated rats were sufficient to maintain the expression of androgen-regulated genes. Together, these data support the hypothesis that in humans and rats, serum androgen levels are not equivalent to prostate tissue androgen levels and that the prostate is able to adapt to variable androgen environments to maintain a functional level of androgens.

In humans, several mechanisms have been shown to contribute to androgen maintenance in the setting of CRPC, many of which may be relevant in intraprostatic androgen maintenance in healthy human and rat prostates as well. Chen et al. (2004) have shown that increased $\mathrm{AR}$ expression is instrumental in the progression from androgen-dependent to castration-resistant growth, with the degree of AR upregulation observed being sufficient to allow tumor cell proliferation in $80 \%$ lower androgen concentrations. We also observed a slight but significant increase in the expression of AR when the prostate was exposed to a low systemic testosterone environment. While this certainly contributes to maintaining AR-dependent signaling, it could also contribute to the increased prostate tissue androgen levels by simply increasing the amount of androgens bound and retained in the prostate. However, the slight increase in $\mathrm{AR}$ expression, the estimated femtomolar concentration of $\mathrm{AR}$, and the presence of a plethora of other ABPs in the prostate suggest that increased androgen retention is not the major mechanism of androgen maintenance in normal rat prostate tissue.

Increased uptake of androgens from the serum is another potential contributor to intraprostatic androgen maintenance. We assessed several genes reported to mediate androgen delivery and uptake in humans, but found none to be significantly altered in the setting of a low-testosterone environment. We did, however, observe slight increases in the expression of $A b p$ and megalin. It is possible that with larger cohorts of animals, these values would have reached statistical significance. ABP, the SHBG homolog, is a well-characterized plasma protein that regulates the level of bioavailable androgens in the blood and has also been shown to be produced by prostate cells and to facilitate androgen entry into cells via interaction with endocytic receptors such as megalin (Hammes et al.
2005), signaling receptors that remain to be identified (Heinlein \& Chang 2002, Kahn et al. 2008), or proteins in the extra-cellular matrix, such as fibulin (Ng et al. 2006). Thus, the increased expression of ABP/SHBG and its receptors such as megalin in prostate tissue may contribute to the cellular uptake of steroid hormones and intraprostatic androgen maintenance.

In addition to the uptake of circulating testosterone and DHT, the conversion of circulating adrenal androgen precursors, primarily DHEAS, has also been reported as a potential source of prostate androgens in CRPC tissue (Bartsch et al. 1990, Labrie et al. 2001, Stanbrough et al. 2006). However, in agreement with previous studies that indicate that rodent species only have very low levels of circulating DHEAS due to a lack of adrenal CYP17 (CYP17A1) expression (Cutler et al. 1978, Ando et al. 1988, Hu et al. 2009a), we could not detect any DHEA in the serum or prostate by ELISA. While an unknown adrenal androgen could contribute to the androgenic content of the rat prostate, the fact that testosterone and DHT were not detected in prostates from castrated rats argues against an adrenal androgen source, since the adrenal gland was intact in these rats. Thus, at least in rats, conversion of adrenal androgens does not appear to contribute to intraprostatic androgen maintenance.

We did observe many significant changes in the expression of enzymes involved in the biosynthesis and metabolism of androgens in response to low serum testosterone levels. Many of these changes were very similar to those that have been reported in PC cells as they transition to castration resistance. We observed an upregulation of the expression of $H s d 3 b 1, H s d 17 b 1$, $H s d 17 b 3, H s d 17 b 6, R d h 5, H s d 17 b 10$, and Srd5a3, all of which would be expected to lead to an increase in testosterone and DHT levels (Fig. 2). In one of the most comprehensive studies to date, Montgomery et al. (2008) observed a similar upregulation in the expression of several of these enzymes in castration-resistant vs androgen-sensitive PC tissue. They also observed a decrease in $S R D 5 A 2$ expression and an increase in SRD5A1 expression. While we did not observe significant changes in these genes, we did find a significant increase in the expression of $\operatorname{Srd5a3}$, the gene encoding an enzyme that can mediate the same conversion of androgens to their $5 \alpha$ metabolites (Uemura et al. 2008). This alternative enzyme usage might be specific to rats vs humans or to the process of intraprostatic androgen maintenance vs the process of castration resistance. Of note, we did not observe the expression of any unusual $A r$ transcripts or AR splice variants, as has been reported in CRPC tissue (Guo et al.

Published by Bioscientifica Ltd. 
2009, Hu et al. 2009b, Hornberg et al. 2011). This suggests that the expression of AR splice variants may be unique to humans and/or the process of castration resistance. The altered expression of genes encoding enzymes in the androgen biosynthesis pathway suggests that increased synthesis of androgens in the prostate may be a major factor in androgen maintenance in the rat prostate in a low systemic testosterone environment, much as it is in the setting of CRPC. Whether the normal rat prostate can synthesize testosterone and DHT de novo from cholesterol remains to be determined.

The Montgomery study also noted significant changes in the metabolic enzymes responsible for the conjugation of glucuronide to androgens, UGT2B15 and UGT2B17. These proteins do not have direct homologs in rats, but we did observe changes in the expression of two genes involved in the sulfate and glucuronide metabolic pathways: Gusb, which encodes the $\beta$-glucuronidase enzyme responsible for the hydrolysis of steroid glucuronides, and Arsc1, which encodes the enzyme responsible for the hydrolysis of $\mathrm{E}_{2}$-3-sulfate as well as DHEAS. Of note, the expression of $\beta$-glucuronidase has been reported to be increased in prostate carcinoma compared with in prostatic hyperplasia (Pearson et al. 1989). Thus, it is possible that these metabolic enzymes participate in the maintenance of intraprostatic androgens.

The Montgomery study also noted a strong increase in the expression of CYP19A1, the gene encoding aromatase. We also observed a significant increase in the expression of Cyp19a1, as well as an increased expression of Sult1e1 and $H s d 17 b 1$, genes encoding enzymes involved in the estrogen synthesis pathway (Falany et al. 1995, Labrie et al. 1997, Ghosh et al. 2009). These changes should lead to increased concentrations of estrogens in the prostate; however, levels of $\mathrm{E}_{2}$ were below the level of detection by ELISA in rat prostates in our study. Tissue estrogen levels have not been comprehensively examined in the setting of CRPC, but several studies have shown that $\mathrm{E}_{1}$ and $\mathrm{E}_{2}$ are not the major estrogens in the prostate and PC tissue (Krieg et al. 1993, Shibata et al. 2000). As aromatase expression and estrogens have been implicated in the development of PC (Kozak et al. 1982, Krieg et al. 1993, Thompson et al. 2002, Ellem \& Risbridger 2010), there is need for further exploration of estrogens in the response to low systemic testosterone levels and in prostate tumorigenesis as well as the development of CRPC.

While the rat model of intraprostatic androgen maintenance has important limitations including differences between the rodent and human endocrine systems and prostate structure (Cutler et al. 1978, Sharma \&
Schreiber-Agus 1999) and the use of continuous testosterone administration that does not reflect the normal diurnal variation or the gradual decline of systemic androgens with age, our data demonstrate that the healthy rat prostate is able to maintain intraprostatic androgens in the presence of low serum androgen levels through mechanisms similar to those that occur in human CRPC.

Although the development of PC is androgen dependent, the incidence of PC actually increases as systemic androgen levels decline with age. Thus, the relationship between PC and aging suggests that it may be a decrease rather than an elevation of systemic androgen levels that facilitates prostate oncogenesis. However, there is no direct mechanistic evidence supporting this hypothesis. In light of our current findings and the findings of others, one interpretation is that low serum androgen levels may put a selective pressure on the prostate and confer a growth advantage upon cells that maintain androgen levels and active AR signaling. Selection for cell survival in the setting of declining systemic testosterone levels has been proposed previously (Prehn 1999), but here we suggest that instead of changes that lead to the selection of androgen-independent cells, low systemic testosterone levels result in the selection of cells with enhanced sensitivity to androgens and greater dependence on AR signaling. Changes in AR signaling might result in a switch from the regulation of cell differentiation genes to the regulation of growthstimulatory genes, as occurs in CRPC (Hoimes \& Kelly 2010). If such changes occur in prostate stem cells, they could lead to the expansion of proliferation-enabled, AR-dependent cells and lead to distinct cancer foci. While we have demonstrated that changes in the androgen/AR signaling axis probably contribute to intraprostatic androgen maintenance, further studies are required to determine whether and how the mechanisms involved in maintaining intraprostatic androgen levels are responsible for prostate tumorigenesis.

\section{Supplementary data}

This is linked to the online version of the paper at http://dx.doi.org/10.1530/ JME-13-0060.

\section{Declaration of interest}

The authors declare that there is no conflict of interest that could be perceived as prejudicing the impartiality of the research reported.

\section{Funding}

This research was funded in part by $\mathrm{NCI}$ CCSG CA033572

Published by Bioscientifica Ltd. 


\section{References}

Abate-Shen C, Banach-Petrosky WA, Sun X, Economides KD, Desai N, Gregg JP, Borowsky AD, Cardiff RD \& Shen MM 2003 Nkx3.1; Pten mutant mice develop invasive prostate adenocarcinoma and lymph node metastases. Cancer Research 63 3886-3890.

Ando S, Canonaco M, Beraldi E, Valenti A, Maggiolini M, Piro A, Tavolaro R \& Dessi Fulgheri F 1988 The evaluation of androgen circulating levels following castration in adult male rats. Experimental and Clinical Endocrinology 91 311-318. (doi:10.1055/s-0029-1210763)

Banach-Petrosky W, Jessen WJ, Ouyang X, Gao H, Rao J, Quinn J, Aronow BJ \& Abate-Shen C 2007 Prolonged exposure to reduced levels of androgen accelerates prostate cancer progression in Nkx3.1; Pten mutant mice. Cancer Research 67 9089-9096. (doi:10.1158/0008-5472. CAN-07-2887)

Bartsch W, Klein H, Schiemann U, Bauer HW \& Voigt KD 1990 Enzymes of androgen formation and degradation in the human prostate. Annals of the New York Academy of Sciences 595 53-66. (doi:10.1111/j.1749-6632. 1990.tb34282.x)

Bosland MC 2000 The role of steroid hormones in prostate carcinogenesis. Journal of the National Cancer Institute. Monographs 27 39-66. (doi:10. 1093/oxfordjournals.jncimonographs.a024244)

Chen CD, Welsbie DS, Tran C, Baek SH, Chen R, Vessella R, Rosenfeld MG \& Sawyers CL 2004 Molecular determinants of resistance to antiandrogen therapy. Nature Medicine 10 33-39. (doi:10.1038/nm972)

Cheng J, Wu Y, Mohler JL \& Ip C 2010 The transcriptomics of de novo androgen biosynthesis in prostate cancer cells following androgen reduction. Cancer Biology \& Therapy 9 1033-1042. (doi:10.4161/cbt.9. 12.11876)

Cutler GB Jr, Glenn M, Bush M, Hodgen GD, Graham CE \& Loriaux DL 1978 Adrenarche: a survey of rodents, domestic animals, and primates. Endocrinology 103 2112-2118. (doi:10.1210/endo-103-6-2112)

Dehm SM, Schmidt LJ, Heemers HV, Vessella RL \& Tindall DJ 2008 Splicing of a novel androgen receptor exon generates a constitutively active androgen receptor that mediates prostate cancer therapy resistance. Cancer Research 68 5469-5477. (doi:10.1158/0008-5472. CAN-08-0594)

Ellem SJ \& Risbridger GP 2010 Aromatase and regulating the estrogen: androgen ratio in the prostate gland. Journal of Steroid Biochemistry and Molecular Biology 118 246-251. (doi:10.1016/j.jsbmb.2009.10.015)

Falany CN, Krasnykh V \& Falany JL 1995 Bacterial expression and characterization of a cDNA for human liver estrogen sulfotransferase. Journal of Steroid Biochemistry and Molecular Biology 52 529-539. (doi:10.1016/0960-0760(95)00015-R)

Feldman HA, Longcope C, Derby CA, Johannes CB, Araujo AB, Coviello AD, Bremner WJ \& McKinlay JB 2002 Age trends in the level of serum testosterone and other hormones in middle-aged men: longitudinal results from the Massachusetts male aging study. Journal of Clinical Endocrinology and Metabolism 87 589-598. (doi:10.1210/jc.87.2.589)

Ghosh D, Griswold J, Erman M \& Pangborn W 2009 Structural basis for androgen specificity and oestrogen synthesis in human aromatase. Nature 457 219-223. (doi:10.1038/nature07614)

Goldenberg SL, Koupparis A \& Robinson ME 2011 Differing levels of testosterone and the prostate: a physiological interplay. Nature Reviews. Urology 8 365-377. (doi:10.1038/nrurol.2011.79)

Guo Z, Yang X, Sun F, Jiang R, Linn DE, Chen H, Kong X, Melamed J, Tepper CG, Kung HJ et al. 2009 A novel androgen receptor splice variant is up-regulated during prostate cancer progression and promotes androgen depletion-resistant growth. Cancer Research 69 2305-2313. (doi:10.1158/0008-5472.CAN-08-3795)

Hammes A, Andreassen TK, Spoelgen R, Raila J, Hubner N, Schulz H, Metzger J, Schweigert FJ, Luppa PB, Nykjaer A et al. 2005 Role of endocytosis in cellular uptake of sex steroids. Cell 122 751-762. (doi:10.1016/j.cell.2005.06.032)
Heinlein CA \& Chang C 2002 The roles of androgen receptors and androgen-binding proteins in nongenomic androgen actions. Molecular Endocrinology 16 2181-2187. (doi:10.1210/me.2002-0070)

Hoimes CJ \& Kelly WK 2010 Redefining hormone resistance in prostate cancer. Therapeutic Advances in Medical Oncology 2 107-123. (doi:10.1177/1758834009356433)

Hornberg E, Ylitalo EB, Crnalic S, Antti H, Stattin P, Widmark A, Bergh A \& Wikstrom P 2011 Expression of androgen receptor splice variants in prostate cancer bone metastases is associated with castration-resistance and short survival. PLOS ONE 6 e19059. (doi:10.1371/journal.pone. 0019059)

Hu M, Xin D, Chen J, Sun G, Wang Y \& Na Y 2009a Changes in the androgen levels in the ventral prostate of spontaneously hypertensive rats after castration. BJU International 104 406-411. (doi:10.1111/j. 1464-410X.2009.08442.x)

Hu R, Dunn TA, Wei S, Isharwal S, Veltri RW, Humphreys E, Han M, Partin AW, Vessella RL, Isaacs WB et al. 2009b Ligand-independent androgen receptor variants derived from splicing of cryptic exons signify hormone-refractory prostate cancer. Cancer Research 69 16-22. (doi:10.1158/0008-5472.CAN-08-2764)

Kahn SM, Li YH, Hryb DJ, Nakhla AM, Romas NA, Cheong J \& Rosner W 2008 Sex hormone-binding globulin influences gene expression of LNCaP and MCF-7 cells in response to androgen and estrogen treatment. Advances in Experimental Medicine and Biology 617 557-564.

Kozak I, Bartsch W, Krieg M \& Voigt KD 1982 Nuclei of stroma: site of highest estrogen concentration in human benign prostatic hyperplasia. Prostate 3 433-438. (doi:10.1002/pros.2990030503)

Krieg M, Nass R \& Tunn S 1993 Effect of aging on endogenous level of $5 \alpha$-dihydrotestosterone, testosterone, estradiol, and estrone in epithelium and stroma of normal and hyperplastic human prostate. Journal of Clinical Endocrinology and Metabolism 77 375-381. (doi:10.1210/jc.77.2.375)

Kyprianou N \& Isaacs JT 1987a Biological significance of measurable androgen levels in the rat ventral prostate following castration. Prostate 10 313-324. (doi:10.1002/pros.2990100405)

Kyprianou N \& Isaacs JT $1987 b$ Quantal relationship between prostatic dihydrotestosterone and prostatic cell content: critical threshold concept. Prostate 11 41-50. (doi:10.1002/pros.2990110106)

Labrie F, Luu-The V, Lin SX, Labrie C, Simard J, Breton R \& Belanger A 1997 The key role of $17 \beta$-hydroxysteroid dehydrogenases in sex steroid biology. Steroids 62 148-158. (doi:10.1016/S0039-128X(96)00174-2)

Labrie F, Luu-The V, Labrie C \& Simard J 2001 DHEA and its transformation into androgens and estrogens in peripheral target tissues: intracrinology. Frontiers in Neuroendocrinology 22 185-212. (doi:10.1006/frne. 2001.0216)

Labrie F, Luu-The V, Belanger A, Lin SX, Simard J, Pelletier G \& Labrie C 2005 Is dehydroepiandrosterone a hormone? Journal of Endocrinology 187 169-196. (doi:10.1677/joe.1.06264)

Locke JA, Guns ES, Lubik AA, Adomat HH, Hendy SC, Wood CA, Ettinger SL, Gleave ME \& Nelson CC 2008 Androgen levels increase by intratumoral de novo steroidogenesis during progression of castration-resistant prostate cancer. Cancer Research 68 6407-6415. (doi:10.1158/00085472.CAN-07-5997)

Marks LS, Mazer NA, Mostaghel E, Hess DL, Dorey FJ, Epstein JI, Veltri RW, Makarov DV, Partin AW, Bostwick DG et al. 2006 Effect of testosterone replacement therapy on prostate tissue in men with late-onset hypogonadism: a randomized controlled trial. Journal of the American Medical Association 296 2351-2361. (doi:10.1001/jama.296.19.2351)

Miyamoto H, Messing EM \& Chang C 2004 Androgen deprivation therapy for prostate cancer: current status and future prospects. Prostate $\mathbf{6 1}$ 332-353. (doi:10.1002/pros.20115)

Moger WH 1976 Effect of testosterone implants on serum gonadotropin concentrations in the male rat. Biology of Reproduction 14 665-669. (doi:10.1095/biolreprod14.5.665)

Mohler JL, Gregory CW, Ford OH III, Kim D, Weaver CM, Petrusz P, Wilson EM \& French FS 2004 The androgen axis in recurrent prostate 
cancer. Clinical Cancer Research 10 440-448. (doi:10.1158/1078-0432. CCR-1146-03)

Montgomery RB, Mostaghel EA, Vessella R, Hess DL, Kalhorn TF, Higano CS, True LD \& Nelson PS 2008 Maintenance of intratumoral androgens in metastatic prostate cancer: a mechanism for castration-resistant tumor growth. Cancer Research 68 4447-4454. (doi:10.1158/0008-5472.CAN08-0249)

Morgentaler A 2009 Testosterone therapy in men with prostate cancer: scientific and ethical considerations. Journal of Urology 181 972-979. (doi:10.1016/j.juro.2008.11.031)

Morgentaler A \& Traish AM 2009 Shifting the paradigm of testosterone and prostate cancer: the saturation model and the limits of androgendependent growth. European Urology 55 310-320. (doi:10.1016/j. eururo.2008.09.024)

Mostaghel EA, Lin DW, Amory JK, Wright JL, Marck BT, Nelson PS, Matsumoto AM, Bremner WJ \& Page ST 2012 Impact of male hormonal contraception on prostate androgens and androgen action in healthy men: a randomized, controlled trial. Journal of Clinical Endocrinology and Metabolism 97 2809-2817. (doi:10.1210/jc.2012-1536)

Nadiminty N \& Gao AC 2012 Mechanisms of persistent activation of the androgen receptor in CRPC: recent advances and future perspectives. World Journal of Urology 30 287-295. (doi:10.1007/s00345-011-0771-3)

Ng KM, Catalano MG, Pinos T, Selva DM, Avvakumov GV, Munell F \& Hammond GL 2006 Evidence that fibulin family members contribute to the steroid-dependent extravascular sequestration of sex hormonebinding globulin. Journal of Biological Chemistry 281 15853-15861. (doi:10.1074/jbc.M512370200)

Page ST, Lin DW, Mostaghel EA, Hess DL, True LD, Amory JK, Nelson PS, Matsumoto AM \& Bremner WJ 2006 Persistent intraprostatic androgen concentrations after medical castration in healthy men. Journal of Clinical Endocrinology and Metabolism 91 3850-3856. (doi:10.1210/jc. 2006-0968)

Page ST, Lin DW, Mostaghel EA, Marck BT, Wright JL, Wu J, Amory JK, Nelson PS \& Matsumoto AM 2011 Dihydrotestosterone administration does not increase intraprostatic androgen concentrations or alter prostate androgen action in healthy men: a randomized-controlled trial. Journal of Clinical Endocrinology and Metabolism 96 430-437. (doi:10.1210/jc.2010-1865)

Pearson JP, Pretlow TP, Bradley EL Jr, McGinnis MC \& Pretlow TG 1989 $\beta$-Glucuronidase activity in prostatic carcinoma and benign prostatic hyperplasia. Cancer 64 911-915. (doi:10.1002/1097-

0142(19890815)64:4 < 911::AID-CNCR2820640425>3.0.CO;2-B)

Prehn RT 1999 On the prevention and therapy of prostate cancer by androgen administration. Cancer Research 59 4161-4164.

Roddam AW, Allen NE, Appleby P \& Key TJ 2008 Endogenous sex hormones and prostate cancer: a collaborative analysis of 18 prospective studies. Journal of the National Cancer Institute 100 170-183. (doi:10.1093/jnci/djm323)

Schatzl G, Madersbacher S, Thurridl T, Waldmuller J, Kramer G, Haitel A \& Marberger M 2001 High-grade prostate cancer is associated with low serum testosterone levels. Prostate 47 52-58. (doi:10.1002/pros.1046)
Sharma P \& Schreiber-Agus N 1999 Mouse models of prostate cancer. Oncogene 18 5349-5355. (doi:10.1038/sj.onc.1203037)

Shibata Y, Ito K, Suzuki K, Nakano K, Fukabori Y, Suzuki R, Kawabe Y, Honma S \& Yamanaka H 2000 Changes in the endocrine environment of the human prostate transition zone with aging: simultaneous quantitative analysis of prostatic sex steroids and comparison with human prostatic histological composition. Prostate 42 45-55. (doi:10.1002/(SICI)1097-0045(20000101)42:1 < 45::AID-PROS6>3.0. CO;2-W)

Shiota M, Yokomizo A \& Naito S 2011 Increased androgen receptor transcription: a cause of castration-resistant prostate cancer and a possible therapeutic target. Journal of Molecular Endocrinology $\mathbf{4 7}$ R25-R41. (doi:10.1530/JME-11-0018)

Smith NF, Figg WD \& Sparreboom A 2005 Role of the liver-specific transporters OATP1B1 and OATP1B3 in governing drug elimination. Expert Opinion on Drug Metabolism \& Toxicology 1 429-445. (doi:10.1517/17425255.1.3.429)

Soronen P, Laiti M, Torn S, Harkonen P, Patrikainen L, Li Y, Pulkka A, Kurkela R, Herrala A, Kaija H et al. 2004 Sex steroid hormone metabolism and prostate cancer. Journal of Steroid Biochemistry and Molecular Biology 92 281-286. (doi:10.1016/j.jsbmb.2004.10.004)

Stanbrough M, Bubley GJ, Ross K, Golub TR, Rubin MA, Penning TM, Febbo PG \& Balk SP 2006 Increased expression of genes converting adrenal androgens to testosterone in androgen-independent prostate cancer. Cancer Research 66 2815-2825. (doi:10.1158/00085472.CAN-05-4000)

Sun S, Sprenger CC, Vessella RL, Haugk K, Soriano K, Mostaghel EA, Page ST, Coleman IM, Nguyen HM, Sun H et al. 2010 Castration resistance in human prostate cancer is conferred by a frequently occurring androgen receptor splice variant. Journal of Clinical Investigation 120 2715-2730. (doi:10.1172/JCI41824)

Thompson CJ, Tam NN, Joyce JM, Leav I \& Ho SM 2002 Gene expression profiling of testosterone and estradiol-17 $\beta$-induced prostatic dysplasia in Noble rats and response to the antiestrogen ICI 182,780. Endocrinology 143 2093-2105. (doi:10.1210/ en.143.6.2093)

Uemura M, Tamura K, Chung S, Honma S, Okuyama A, Nakamura Y \& Nakagawa H 2008 Novel $5 \alpha$-steroid reductase (SRD5A3, type-3) is overexpressed in hormone-refractory prostate cancer. Cancer Science $\mathbf{9 9}$ $81-86$.

Vanderschueren D, Vandenput L, Boonen S, Van Herck E, Swinnen JV \& Bouillon R 2000 An aged rat model of partial androgen deficiency: prevention of both loss of bone and lean body mass by low-dose androgen replacement. Endocrinology 141 1642-1647. (doi:10.1210/en. 141.5.1642)

Waltering KK, Helenius MA, Sahu B, Manni V, Linja MJ, Janne OA \& Visakorpi T 2009 Increased expression of androgen receptor sensitizes prostate cancer cells to low levels of androgens. Cancer Research 69 8141-8149. (doi:10.1158/0008-5472.CAN-09-0919)

Received in final form 17 May 2013

Accepted 24 May 2013

Accepted Preprint published online 24 May 2013 http://jme.endocrinology-journals.org DOI: 10.1530/JME-13-0060
(ㄷ) 2013 Society for Endocrinology Printed in Great Britain
Published by Bioscientifica Ltd. 